\title{
Erratum to: Structural aspects of human lactoferrin in the iron-binding process studied by molecular dynamics and small-angle neutron scattering
}

\author{
The Publishers \\ EDP Sciences, Società Italiana di Fisica and Springer-Verlag GmbH Germany, part of Springer Nature
}

Original article: Eur. Phys. J. E (2018) 41: 109, https://doi.org/10.1140/epje/i2018-11720-x

Received: 7 November 2018

Published online: 16 November 2018

(C) The Author(s) 2018. This article is published with open access at Springerlink.com

The article Structural aspects of human lactoferrin in the iron-binding process studied by molecular dynamics and small-angle neutron scattering, written by Lilia Anghel, Aurel Radulescu, Raul Victor Erhan, was originally published electronically on the publisher's internet portal (currently SpringerLink) on 20 September 2018 without open access. With the author(s)' decision to opt for Open Choice the copyright of the article changed on 16 November 2018 to (C)The Author(s) 2018 and the article is forthwith distributed under the terms of the Creative Commons Attribution 4.0 International License (http://creativecommons.org/licenses/by/4.0/), which permits use, duplication, adaptation, distribution and reproduction in any medium or format, as long as you give appropriate credit to the original author(s) and the source, provide a link to the Creative Commons license and indicate if changes were made.

Open Access This is an open access article distributed under the terms of the Creative Commons Attribution License (http://creativecommons.org/licenses/by/4.0), which permits unrestricted use, distribution, and reproduction in any medium, provided the original work is properly cited. 